\title{
The effect of dietary levels of yellow lupin seeds (Lupinus luteus L.) on feed preferences and growth performance of young pigs
}

\section{Bugnacka and J. Falkowski}

\author{
Department of Pig Breeding, \\ University of Warmia and Masuria in Olsztyn \\ Oczapowskiego 5, 10-718 Olsztyn, Poland
}

(Received 22 November 1999; revised version 10 August 2000; accepted 22 January 2001)

\section{ABSTRACT}

Feed preference (Experiment I) and growth performance tests (Experiment II) were carried out on growing pigs fed on diets differing in yellow lupin levels. In Experiment I, dietary choices were determined using the single stimulus method on 12 individually kept young pigs. In Experiment II, basic growth parameters were studied in 36 young pigs. Three diets were used: control (1), with soyabean meal (SBM) as the only high-protein component, and experimental diets in which lupin protein substituted for 75 (diet 2) or 100\% (diet 3) of SBM protein. The lupin content in diets 2 and 3 was 19 and $25 \%$, respectively.

During a 28-day feed preference test, daily intake of the three diets amounted to 760,736 and $700 \mathrm{~g}$, respectively; the differences are statistically significant. The average daily weight gains and feed intake were similar, while the best feed conversion ratio was in pigs fed on the diet with $19 \%$ yellow lupin seed meal.

KEY WORDS: pigs, nutrition, yellow lupin, cv. Juno, feed preferences, growth performance

\section{INTRODUCTION}

The use of leguminous plant seeds in the diets for monogastric animals is restricted due to the antinutritional factors contained in these seeds. Alkaloids are 
considered the most important factors in lupin seeds. This is one of the reasons why the optimum content of lupin in the diets for pigs, and especially for young piglets, has never been established in an unequivocal way. Low-alkaloid sweet lupin varieties have been produced to eliminate the negative effects of these factors on animal health and performance and to make utilization of this highprotein feed in pig nutrition possible as a partial or even total substitute for soyabean meal (Kemm et al., 1987; Flis, 1993).

Some experiments showed that even a relatively high content of lupin seeds did not affect the performance of piglets and young growing pigs (37\%, Pearson and Carr, 1976; 43\%, Barnett and Batterham, 1981). Böhme (1988) found that supplementing the diet with up to $30 \%$,Topaz" yellow lupin seeds had a positive effect on the performance of weaned pigs $(10-25 \mathrm{~kg})$. In the experiment carried out by Gdala et al. (1996) it was concluded that seeds of yellow and narrow-leaved lupin could be used at a level of up to $41 \%$ in diets without depressing growth performance as compared with a soyabean diet. On the other hand, the results of other experiments suggested that lupin seeds could be used in pig feeding at a much lower dietary level (King, 1981; Donovan et al., 1993; McNiven and Castell, 1995).

Many studies have shown the negative effects of alkaloid- (Godfrey et al., 1985; Kemm et al., 1987), high crude fibre- (McNiven and Castell, 1995), and low lysine- (Batterham et al., 1986b) contents of lupin seeds, but primarily, of their low methionine level (Eggum ct al., 1993). Godfrey et al. (1985) recommended that the diets of pigs fed ad libitum should not contain more than $0.20 \mathrm{~g} / \mathrm{kg}$ of alkaloids. These authors found that an increase of alkaloid levels from 0.12 to $0.52 \mathrm{~g} / \mathrm{kg}$ resulted in a progressive decrease of daily weight gains and feed intake by piglets. An increase in the alkaloid level by $0.1 \mathrm{~g} / \mathrm{kg}$ was accompanied by a decrease of daily gains by $47 \mathrm{~g}$ on average, and of feed intake by $0.12 \mathrm{~kg} /$ day. However, alkaloid composition and type are also very important. In the case of white- and narrow-leaved lupin, the main alkaloids are lupanine and sparteine, considered more detrimental than the less-toxic lupinine, which is the dominant alkaloid in yellow lupin (Hill, 1977; Ballester et al., 1980). This is why yellow lupin seeds are regarded as more suitable for pigs.

So far, however, there have been no studies on the effect of high lupin levels on the palatability of diets for young growing pigs or on feed preferences and performance of young pigs.

The objective of this study was to determine the suitability of diets containing high levels of meal from raw seeds of Polish sweet yellow lupin cv. „Juno" for young pigs. Two criteria were used to evaluate the diets: 1. the results of the feed preference test (Experiment I) and 2. the growth performance test (Experiment II). 


\section{MATERIAL AND METHODS}

\section{Composition of the diets}

Three complete diets of the grower type (17.5\% crude protein) were prepared according to Nutrient Requirements of Pigs (1993) (Table 1). In the control diet (1), soyabean meal was the only high-protein component. In diet 2 raw ground seeds of sweet yellow lupin, Polish variety „Juno”, constituted $19 \%$ of the diet, replacing $75 \%$ of the soyabean meal protein. In diet 3, lupin ,Juno" replaced $100 \%$ of the soyabean meal protein, constituting $25 \%$ of the diet. Feeds were supplemented with lysine and methionine according to Polish standards.

TABLE 1

Composition and nutritive value of diets for young pigs (Experiments I and II)

\begin{tabular}{|c|c|c|c|}
\hline \multirow{2}{*}{ Indices } & \multicolumn{3}{|c|}{ Diets } \\
\hline & 1 & 2 & 3 \\
\hline \multicolumn{4}{|l|}{ Ingredients, $\%$} \\
\hline ground barley & 44.10 & 40.07 & 40.02 \\
\hline ground wheat & 30.00 & 30.00 & 30.00 \\
\hline soyabean meal & 21.00 & 6.00 & - \\
\hline lupin (L. luteus cv. Juno) seed meal & - & 19.00 & 25.00 \\
\hline Formosan * & 3.10 & 3.10 & 3.10 \\
\hline PP - prestarter premix $* *$ & 1.50 & 1.50 & 1.50 \\
\hline L - lysine $(99 \%)$ & 0.25 & 0.25 & 0.28 \\
\hline DL - methionine $(99 \%)$ & 0.05 & 0.08 & 0.10 \\
\hline \multicolumn{4}{|l|}{ Chemical composition, \% DM } \\
\hline dry matter & 90.28 & 90.00 & 90.18 \\
\hline crude protein & 18.02 & 18.38 & 18.03 \\
\hline crude fat & 1.66 & 1.91 & 1.92 \\
\hline crude fibre & 3.96 & 5.80 & 6.16 \\
\hline $\mathrm{N}$ - free extractives & 60.14 & 58.24 & 58.08 \\
\hline crude ash & 6.50 & 5.67 & 5.99 \\
\hline organic matter & 83.78 & 84.33 & 84.19 \\
\hline total alkaloids, $\mathrm{g} / \mathrm{kg} \mathrm{DM}$ & - & 0.074 & 0.097 \\
\hline \multicolumn{3}{|l|}{ Metabolizable energy, $\mathrm{MJ} / \mathrm{kg}$} & 12.54 \\
\hline
\end{tabular}

* Formosan contains per $1 \mathrm{~kg}$ : Ca, 275,0 g; P, 77,0 g; Na, 32,5 g; Cl, 23,2 g; Mg, 9,0 g; Zn, 2,0 g; $\mathrm{Fe}, 0,78 \mathrm{~g} ; \mathrm{Cu}, 0,20 \mathrm{~g} ; \mathrm{Mn}, 0,63 \mathrm{~g} ; \mathrm{Co}, 0,04 \mathrm{~g} ; \mathrm{J}, 0,02 \mathrm{~g} ; \mathrm{S}, 0,60 \mathrm{~g}$

** PP - prestarter premix contains per $1 \mathrm{~kg}$ : vit. A, $500.000 \mathrm{IU}$; vit. $\mathrm{D}_{3}, 100.000 \mathrm{IU}$; vit. E, $0,75 \mathrm{~g}$; vit. $\mathrm{K}_{3}, 0,15 \mathrm{~g}$; vit. $\mathrm{B}_{1}, 0,06 \mathrm{~g}$; vit. $\mathrm{B}_{2}, 0,125 \mathrm{~g}$; vit. $\mathrm{B}_{12}, 0,0015 \mathrm{~g}$; biotin, $0,01 \mathrm{~g}$; nicotinic acid, 0,5 $\mathrm{g}$; calcium pantothenate, $0,4 \mathrm{~g}$; Mn, $1,0 \mathrm{~g} ; \mathrm{Co}, 0,005 \mathrm{~g} ; \mathrm{Zn}, 2,25 \mathrm{~g} ; \mathrm{Cu}, 0,25 \mathrm{~g} ; \mathrm{Fe}, 3,5 \mathrm{~g}$; J, 0,025 $\mathrm{g}$; tylosine, $2,0 \mathrm{~g}$; anti-oxidante, $5,0 \mathrm{~g}$; carrier up, to $1000 \mathrm{~g}$ 
Nutrient contents in the diets and yellow lupin „Juno" were analysed according to the Weende method (Tables 1 and 2). Total alkaloid content in lupin seeds was determined by the method of Wysocka ct al. (1989). The contents of crude fibre, neutral detergent fibre (NDF), acid detergent fibre (ADF) and acid detergent lignin (ADL) in lupin seeds were determined using Fibertec System M by methods described by Van Soest and Wine (1967) and Van Soest (1973). Cellulose and hemicellulose contents were calculated based on NDF, ADF and ADL. The essential amino acid contents of "Juno" seeds was determined with an automatic analyser AAAT 339 Mikrotechna, tryptophan was analysed according to Eggum (1968).

\section{Experimental design}

Feed preference test (Experiment I). Twelve young pigs (crosses of $q$ Polish Landrace $x$ o Polish Large White), aged 8 weeks, of initial body weight $22.5 \mathrm{~kg}$, were selected based on sex, litter and liveweight (analogue method). Each was

TABLE 2

Chemical composition of yellow lupin seed cv. Juno

\begin{tabular}{lr}
\hline Specification & Yellow lupin \\
\hline Chemical composition, \% DM & \\
dry matter & 91.72 \\
crude protein & 42.15 \\
crude fat & 3.76 \\
crude ash & 4.92 \\
crude fibre & 16.52 \\
NDF & 23.07 \\
ADF & 19.38 \\
ADL & 0.44 \\
cellulose & 18.95 \\
hemicellulose & 3.68 \\
alkaloids & 0.039 \\
& \\
Essential amino acids, g per $16 \mathrm{~g} \mathrm{~N}$ & \\
His & 2.63 \\
Lys & 4.97 \\
Phe + Tyr & 7.05 \\
Met + Cys & 2.90 \\
Thr & 3.37 \\
Trp & 0.84 \\
Ile & 4.29 \\
Leu & 7.53 \\
Val & 4.19 \\
\hline
\end{tabular}


placed in a $0.7 \times 1.2 \mathrm{~m}$ flat-deck cage (with slatted floor), in an experimental pig unit. The cages had automatic feeders and nipple watering containers.

The feed preference test lasted 28 days and was carried out using the single stimulus method of Aldinger and Fitzgerald (1966), used also in other experiments (e.g. Baidoo et al., 1986; Falkowski et al., 1998). Each day the animals had free access, successively for $4 \mathrm{~h}$ (from 8.00 to $20.00 \mathrm{~h}$ ), to each of the three feeds. The sequence of feeds changed every day, so that the pigs could not get accustomed to a particular feed. Feed intake was controlled each day. The animals were weighed on days 1,14 and 28 of the experiment.

Growth performance test (Experiment II). Growth performance was evaluated during 28 days on 36 young pigs (crosses of $q$ Polish Landrace $x$ o Polish Large White) aged 8 weeks, of initial body weight $18.8 \mathrm{~kg}$. They were allocated to the three groups according to the analogue method. Two animals (a male and a female) each were placed in a flat-deck cage $(0.7 \times 1.2 \mathrm{~m})$. The animals were fed $\mathrm{ad}$ libitum on diets of the composition as in Experiment I. Pigs were weighed on days 1,14 and 28 , feed intake and animal health were controlled daily.

\section{Statistical analysis}

The data were analysed statistically with a one-way analysis of variance and the Duncan's test. The statistical programme SPSS (1995) was used.

\section{RESULTS AND DISCUSSION}

The chemical composition of the diets is presented in Table 1 . The increase of raw fibre content in diets 2 and 3 was due to the relatively high content of CF in lupin seeds $(16.52 \%)$.

The alkaloid content in lupin was $0.039 \%$ of DM (Table 2), which is lower than the acceptable level for sweet (low-alkaloid) lupin $0.05 \% \mathrm{DM}$, but higher than the level accepted in commercial seeds in the European Union $(0.02 \% \mathrm{DM})$ and Australia $(0.01 \% \mathrm{DM})$.

In the first period of Experiment I (days 1-14), the average feed intake did not differ significantly between the groups (Table 3), while in the sccond period it decreased as the lupin level increased. This tendency was maintained in the whole experiment, but only the diet with the highest lupin level was consumed at a significantly lower rate than the control one $(760 \mathrm{~g}$ for the control diet, and 736 and $700 \mathrm{~g}$ for dicts 2 and 3, respectively), which may be explained by the negative effect of lupin alkaloids on diet palatability. A similar experiment, performed on weaned piglets given diets in which narrow-leaved lupin „Emir" was used at a 
TABLE 3

Average daily intake of diets per pig, $g$ (Experiment $l$ )

\begin{tabular}{|c|c|c|c|c|}
\hline \multirow{2}{*}{$\begin{array}{c}\text { Period of experiment } \\
\text { days }\end{array}$} & \multirow{2}{*}{$\begin{array}{c}\text { Total } \\
\text { daily intake }\end{array}$} & \multicolumn{3}{|c|}{ Daily intake of diets } \\
\hline & & 1 & 2 & 3 \\
\hline & & \multicolumn{3}{|c|}{ Dietary alkaloids, g/kg DM } \\
\hline & & - & 0.074 & 0.097 \\
\hline \multicolumn{5}{|l|}{$1-14$} \\
\hline$\ddot{x}$ & 1946 & 655 & 651 & 641 \\
\hline s & 213.1 & 85.1 & 80.1 & 89.3 \\
\hline$\%$ & 100 & 34 & 33 & 33 \\
\hline \multicolumn{5}{|l|}{$15-28$} \\
\hline $\bar{x}$ & 2444 & $865^{\mathrm{A}}$ & $82 l^{\mathrm{B}}$ & $759^{\circ}$ \\
\hline $\mathbf{s}$ & 297.1 & 107.6 & 129.1 & 142.1 \\
\hline$\%$ & 100 & 35 & 34 & 31 \\
\hline \multicolumn{5}{|l|}{$1-28$} \\
\hline$\ddot{x}$ & 2195 & $760^{\wedge a}$ & $736^{\mathrm{Ab}}$ & $700^{\mathrm{B}}$ \\
\hline$s$ & 358.9 & 142.7 & 137.4 & 132.6 \\
\hline$\%$ & 100 & 35 & 33 & 32 \\
\hline
\end{tabular}

A.3.C. $-P \leq 0.01 ;$ a.b $-P \leq 0.05$

level of $14 \%$ and replaced $50 \%$ of the soyabean protein, showed that there was no effect of lupin on palatability as compared with the control cereal-soyabean diet (Falkowski and Jabłonowski, 1993).

The pigs showed very good growth performance throughout the experiment, as reflected by high body weight gains averaging $902 \mathrm{~g}$ (918 and $886 \mathrm{~g}$ in the first and the second period of the experiment, respectively). In the previous feed preference tests it was also found that the pigs that were allowed to consume more than one feed tended to eat more and to grow faster than normally fed pigs (Baidoo et al., 1986; Falkowski et al., 1998).

In Experiment II, no statistically significant effect of the experimental diets on pig body weight and growth rate was found, but the highest body weight on days 14 and 28 was observed in group 2 fed diets containing 19\% of lupin seeds (Table 4).

Average daily feed intake per animal (Table 4) in the first period of the experiment did not differ between groups, ranging from $1.19 \mathrm{~kg}$ in group 1 to $1.23 \mathrm{~kg}$ in group 3. Similar tendencies were observed in the second period. In the experiment of Böhme (1988), yellow lupin „Topaz" at the level of 30\% increased feed intake of weaned piglets up to $7 \%$. The addition of $25.4 \%$ of white lupin „Ultra" to the diet for growing pigs significantly increased feed intake in the experiment carried 
out by Batterham (1979), while Kemm et al. (1987) found that when the diets for early weaned pigs were supplemented with $12 \%$ of white lupin „Buttercup" seeds containing $0.05 \%$ of alkaloids, feed intake decreased by $21 \%$.

In the whole period of the experiment, daily weight gains were 676,706 and $693 \mathrm{~g}$ in the three groups respectively, being a little higher in the experimental groups than in the control (Table 4). Daily weight gains obtained in our experiment were similar to those observed by King (1981) (622-693 g) and Donovan et al. (1993) (610-750 g), but slightly lower than those presented by Godfrey et al. (1985) (776-817 g). Lower daily gains (510-528 g) were obtained by Böhme (1988)

TABLE 4

Growth performance of pigs (Experiment II)

\begin{tabular}{lllll}
\hline Specification & $\begin{array}{c}\text { Period of } \\
\text { experiment days }\end{array}$ & & \multicolumn{3}{c}{ Diets } \\
\cline { 3 - 5 } & & & 2 & 3 \\
\hline
\end{tabular}

Dietary alkaloids, g/kg DM

$0.074 \quad 0.097$

Average initial body weight, kg

$\overline{\mathrm{x}}$

S

Average daily feed intake, $\mathrm{kg}$ per pig

$\bar{x}$
$s$
$\bar{x}$
$s$
$\bar{x}$
$s$

$\bar{x}$

$s$

$\overline{\mathrm{x}}$

$s$

$\overline{\mathrm{x}} \quad 1-28$

s

Average daily gain, g

Feed/gain ratio

\begin{tabular}{lllll}
$\overline{\mathrm{x}}$ & $1-14$ & 542 & 597 & 578 \\
$\mathrm{~s}$ & & 174 & 183 & 163 \\
$\overline{\mathrm{x}}$ & $15-28$ & 810 & 815 & 808 \\
$\mathrm{~s}$ & & 164 & 166 & 136 \\
$\overline{\mathrm{x}}$ & $1-28$ & 676 & 706 & 693 \\
$\mathrm{~s}$ & & 215 & 205 & 189 \\
& & & & \\
$\overline{\mathrm{x}}$ & $1-14$ & $2.28^{\mathrm{A}}$ & $2.09^{13}$ & $2.26^{\wedge}$ \\
$\mathrm{s}$ & & 0.54 & 0.39 & 0.63 \\
$\overline{\mathrm{x}}$ & $15-28$ & 2.35 & $2.24^{\mathrm{B}}$ & $2.42^{\wedge}$ \\
$\mathrm{s}$ & & 0.48 & 0.51 & 0.47 \\
$\overline{\mathrm{x}}$ & $1-28$ & $2.31^{\wedge}$ & $2.17^{\mathrm{A}}$ & $2.34^{\wedge}$ \\
$\mathrm{s}$ & & 0.51 & 0.46 & 0.56 \\
\hline
\end{tabular}

18.9

$\begin{array}{rrr}8.7 & 18.9 & \\ 5.6 & 4.3 & 3.2\end{array}$

1.19

1.21

1.23

0.33

0.31

0.29

1.86

1.79

1.92

0.35

0.40

0.32

1.52

1.49

1.58

0.48

0.46

0.46 
in an experiment with diets containing yellow lupin and by Gdala et al. (1996) (391-416 g), when the inclusion level of lupin sced meal (white, yellow or narrowleaf) in barley-based diets for young pigs ranged from 31 to $41 \%$.

The feed conversion ratio differed significantly between the experimental groups, both in the first and the second period (Table 4). The animals in group 2 on the diet containing $19 \%$ of yellow ,Juno" lupin seeds utilized the feed better than the other animals $(2.17 \mathrm{~kg} / \mathrm{kg}$ of body weight gain for the whole period of the experiment). Similar results were presented by Batterham et al. (1986a) (1.98-2.53 kg/kg BW), while a better feed conversion ratio was obtained by Gdala et al. (1996) (1.65-1.78 $\mathrm{kg} / \mathrm{kg}$ ) and Böhme (1988) (1.50-1.57 kg/kg). King's suggestion (1981) that increasing levels of lupin in the diet significantly reduced growth performance and increased feed conversion ratio has not been confirmed.

The relatively high content of alkaloids in the diet did not have a negative effect on growth performance of the pigs, but was probably the reason for worse feed utilization in pigs on the diet with the high lupin seed content $(25 \%)$, which replaced $100 \%$ of soyabean meal proteins (Table 4 ).

\section{CONCLUSIONS}

Increasing the content of yellow lupin seeds from 0 to 19 and $25 \%$ in the diets negatively affected the feed preferences of young growing pigs. However, the average growth rate and daily feed intake during the growth performance test were similar and the feed conversion ratio was the best on the diet containing $19 \%$ of yellow lupin seed meal.

Yellow lupin seeds may be used as a partial substitute of soyabean meal for young pigs fed on diets supplemented with lysine and methionine.

\section{REFERENCES}

Aldinger S.M., Fitzgerald M.F., 1966. New method for testing palatability of baby pig rations. J. Anim. Sci. 25, 887-888 (Abstr.)

Baidoo S.K., Mc Intosh M.K., Aherne F.H., 1986. Selection preference of starter pigs fed canola meal and soybean meal supplemented diets. Can. J. Anim. Sci. 66, 1039-1049

Ballester D., Yanez E., Garcia R., Erazo S., Lopez F., I Iaardt E., Cornejo S., Lopez A., Pokniak J., Chichester C.O., 1980. Chemical composition, nutritive value and toxicological cvaluation of two species of sweet lupin (Lupinus albus and Lupinus luteus). J. Agr. Food Chem. 28, 402-405

Barnetl C.W., Batterham E.S., 1981. Lupinus angustifolius cv. Unicrop as protein - and energysource for weaner pigs. Anim. Feed Sci. Tech. 6, 27-34

Batterham E.S., 1979. Lupinus albus cv. Ultra and Lupinus angustifolius cv. Unicrop as protein concentrates for growing pigs. Aust. J. Agr. Res. 30, 369-375 
Batterham E.S., Andersen L.M., Burnham B.V., Taylor G.A., 1986a. Effect of heat on the nutritiona! value of lupin (Lupinus angustifolius) - seed meal for growing pigs. Brit. J. Nutr. 55, 169-177

Batterham E.S., Andersen L.M., Lowe R.F., Darnell R.E., 1986b. Nutritional value of lupin (Lupinus albus) - seed meal for growing pigs: availability of lysine, effect of autoclaving and net energy content. Brit. J. Nutr. 56, 645-659

Böhme H., 1988. Untersuchungen über die Eignung von Ackerbohnen (Vicia faba), Felderbsen (Pisum sativum) und Süßlupinn (Lupinus luteus) als Eiweißfuttermittel in der Ferkelauzucht. Landbauforsch. Völkenrode 38, 353-358

Donovan B.C., MeNiven M.A., van Lunen T.A., Anderson D.M., MacLedu J.A., 1993. Replacement of soyabean meal with dehydrated lupin seeds in pig diets. Anim. Feed Sci. Tech. 43, 77-85

Eggum B.O., 1968. Detcrmination of tryptophan. Acta Agr. Scand. 18, 127-131

Eggum B.O., Tomes G., Beames R.M., Datta F.U., 1993. Protein and energy evaluation with rats of seed from 11 lupin cultivars. Anim. Feed Sci. Tech. 43, 109-119

Falkowski J., Jabłonowski K., 1993. Suitability of the mixtures containing field bean, field pea and lupin for piglet feeding. I. Estimation of the mixture taste. Acta Acad. Agr. Tech. Olst., Zoot. 38 , $81-88$

Falkowski J., Kozera W., Bugnacka D., 1998. Effect of different salt (NaCl) content of diets on feed preferences of weaned pigs. Natur. Sci. 1, 51-58

Flis M., 1993. Nutritive value for pigs of the seeds of new faba bean and yellow lupin varieties. Acta Acad. Agr. Tech. Olst., Zoot., Suppl. A, 38, 1-47

Gdala J., Jansman A.J.M., van Leeuwen P., Huisman J., Verstegen M.W.A., 1996. Lupins (L. luteus, L. albus, L. angustifolius) as a protein source for young pigs. Anim. Feed Sci. Tech. 62, 239-249

Godfrey N.W., Mercy A.R., Emms Y., Payne H.G., 1985. Tolerance of growing pigs to lupin alkaloids. Aust. J. Exp. Agr. 25, 791-795

Hill G.D. 1977. The composition and nutritive value of lupin seed. Nutr. Abstr. Rev. B, 47, 511-529

Kemm E.J., Minnar J.P., Ras M.N., Davie S.J., 1987. Lupin seed meal (Lupinus albus cv. Buttercup) as a source of protein for early weaned piglets. S. Afr. J. Anim. Sci. 17, 37-42

King R.H., 1981. Lupin-seed meal (Lupinus albus cv. llamburg) as a source of protein for growing pigs. Anim. Feed Sci. Tech. 6, 285-296

McNiven M.A., Castell A.G., 1995. Replacement of soybean meal with lupinseed (Lupinus albus) in pig starter diets. Anim. Feed Sci. Tech. 52, 333-338

Nutrient Requirements of Pigs. Nutritive Value of Feedstuffs (in Polish), 1993. The Kielanowski Institute of Animal Physiology and Nutrition (Editor). Jabłonna (Poland)

Pearson G., Carr J.R., 1976. Lupin-seed meal (Lupinus angustifolius cv. Uniwhite) as a protein supplement to barley-based diets for growing pigs. Anim. Feed Sci. Tech. 1, 631-642

SPSS, 1995. Statistic Package for Social Sciences. Microsoft for Windows. Realise 6.1

Van Soest P.J., 1973. Collaborative study of acid detergent fiber and lignin. J. Assoc. Agr. Chem. 56, $781-782$

Van Socst P.J., Wine R.H., 1967. Use of detergents in the analysis of fibrous feeds. IV. Determination of plant cell wall constituents. J. Assoc. Agr. Chem. 50, 513-530

Wysocka W., Brukwicki T., Jaloszyński R., Hoffman K., 1989. A new and efficient method of extrac* tion of alkaloids from lupin seeds. Lupin Newslett. 13, 59-65 


\section{STRESZCZENIE}

Wplyw mieszanek z różnym udzialem nasion lubinu żóltego (Lupinus luteus L.) na smakowitość i wyniki odchowu mlodych, rosnących świń

Badano 3 diety: 1 . kontrolną, w której jedynym składnikiem wysokobiałkowym była poekstrakcyjna śruta sojowa; 2 . w której $75 \%$ białka ogólnego poekstrakcyjnej śruty sojowej zastąpiono białkiem ogólnym łubinu żółtego; jego udział w diecie wynosił 19\%;3. 100\% białka ogólnego poekstrakcyjnej śruty sojowej zastąpiono białkiem łubinu żółtego; jego udział w diecie wynosił $25 \%$. Przeprowadzono 2 doświadczenia: (I) test preferencji pasz i (II) odchów prosiąt. W doświadczeniu I na 12 indywidualnie utrzymywanych młodych, rosnących świniach ( $\uparrow$ polska biała zwisłoucha x $\delta$ wielka biała polska) badano preferencje pokarmowe wykorzystując metodę pojedynczego bodźca. W doświadczeniu II na 36 młodych, rosnących świniach (takich samych mieszańcach jak w doświadczeniu I), badano podstawowe parametry zootechniczne.

Podczas 28-dniowego testu preferencji pasz średnie dzienne spożycie 3 mieszanek wynosiło odpowiednio: $760,736,700 \mathrm{~g}$ i różniło się istotnie. Średnie dzienne przyrosty i średnie dzienne spożycie paszy przez 1 świnię w okresie odchowu były zbliżone. Wykorzystanie paszy na $1 \mathrm{~kg}$ przyrostu masy ciała było najlepsze przy stosowaniu diety z 19\% udziałem śruty z nasion łubinu żółtego. 